\title{
Goodpasture syndrome as a rare cause of massive respiratory tract hemorrhage
}

\section{Zespół Goodpasture’a jako rzadka przyczyna masywnego krwawienia do dróg oddechowych}

\author{
Małgorzata Wojtyśn ${ }^{凶}$, Piotr Waloszczyk², Jacek Alchimowicz¹, Norbert Wójcik¹, Bogumit Maciąg1, \\ Piotr Lisowskiª Janusz Wójcik', Tomasz Grodzki ${ }^{1}$ \\ 1 Pomorski Uniwersytet Medyczny w Szczecinie, Klinika Chirurgii Klatki Piersiowej i Transplantacji, ul. Sokołowskiego 11, 70-891 Szczecin \\ Pomeranian Medical University in Szczecin, Department of General Thoracic Surgery and Transplantation \\ ${ }^{2}$ Niepubliczny Zakład Opieki Zdrowotnej Zdunomed, ul. Energetyków 2, 70-656 Szczecin \\ Zdunomed Private Health Care Institution \\ ${ }_{3}^{3}$ Pomorski Uniwersytet Medyczny w Szczecinie, Studenckie Koło Naukowe Kliniki Chirurgii Klatki Piersiowej i Transplantacji, ul. Sokołowskiego 11, 70-891 Szczecin \\ Pomeranian Medical University in Szczecin, Students' Scientific Circle of the Department of Thoracic Surgery and Transplantation \\ $\triangle$ margaretkaw@wp.pl
}

\begin{abstract}
In this study, the cases of a patient with Goodpasture syndrome (also referred to as anti-glomerular basement membrane disease) and a patient with the morphological features of Goodpasture syndrome or Goodpasture-like syndrome found in a histopathological examination are described. In both cases the course of the disease was atypical, with a massive respiratory tract hemorrhage being the most significant symptom. Accordingly,
\end{abstract}

the presented patients were treated surgically. Furthermore, the paper described diagnostic difficulties in identifying the cause of the hemorrhage. Finally, the importance of histopathological examination in the diagnosis of Goodpasture syndrome and the Goodpasture-like syndrome with atypical course is emphasized. Keywords: anti-glomerular basement membrane disease; pulmonary-renal syndrome; alveolar hemorrhage; histopathological examination; surgical treatment.

\begin{abstract}
ABSTRAKT
Opisano przypadek chorego z zespołem Goodpasture'a i chorej u której obraz morfologiczny w badaniu histopatologicznym wskazywał na zespół Goodpasture’a lub zespół Goodpasture-like. U obojga pacjentów przebieg choroby był nietypowy, zaś najważniejszym objawem było masywne krwawienie do dróg oddechowych. Z tego powodu opisywani chorzy byli leczeni chirurgicznie. Przedstawiono trudności diagnostyczne w rozpoznaniu
\end{abstract}

\section{INTRODUCTION}

The simultaneous presence of glomerulonephritits, bleeding in the alveoli, and antibodies targeting the basal membrane of the glomeruli is known as Goodpasture syndrome, also referred to as anti-glomerular basement membrane disease. It was first described by Stanton and Tange in 1958 in a report concerning a series of patients presenting these 3 pathological phenomena. The syndrome was named in commemoration of Ernest Goodpasture - the 1st author to mention the co-occurrence of these symptoms in 1919 [1].

Goodpasture syndrome is a rare disease with an occurrence rate of $0.5^{-2}$ cases in a million per year (most commonly referred to as 1 in a 1 million) and a slight predominance in male patients. It can occur at any age from childhood to late adulthood (there are case reports of patients ranging 5-90 years of age $[2,3,4])$. However, the syndrome has 2 "peaks" of occurrence. The 1st includes younger patients in the 5-40 years range. In this group we observe a predominance of male patients, often presented with bleeding in the respiratory tract. The 2nd "peak" includes the 60+ year old patients - this group przyczyny krwawienia. Podkreślono znaczenie badania histopatologicznego w rozpoznaniu zespołu Goodpasture'a i zespołu Goodpasture-like w przypadkach o nietypowym przebiegu. Słowa kluczowe: choroba związana z przeciwciałami przeciwko błonie podstawnej; zespół płucno-nerkowy; krwawienie pęcherzykowe; badania histopatologiczne; leczenie chirurgiczne.

comprises females with the only symptom being glomerulonephrititis $[2,3,4]$.

Goodpasture syndrome is a disease built upon an autoimmunological background - the presence of antibodies specific to the epitopes of the alfa-3 chain in type IV collagen - a basal membrane component of both the glomeruli and alveoli $[1,2,3]$. These antibodies may be related to the change in the conformation of the alfa chain in the collagen so that it becomes an epitope - an immunological target for the antibodies [2]. Furthermore, genetic and environmental factors, like viral infection or air pollution, may also be involved in the initiation of the process. In addition, a more frequent occurrence of the syndrome in spring and early summer has also been reported [4].

Progressive renal failure and alveolar hemorrhage are the most significant symptoms of Goodpasture syndrome. Therefore the disease often has a severe, life-threatening course [2]. Clinically, $60-80 \%$ of the cases are presented with both pulmonary and renal involvement, $20-40 \%$ with solely renal symptoms, and less than $10 \%$ with only signs of pulmonary dysfunction. The respiratory tract hemorrhage concerns over $2 / 3$ of patients with Goodpasture syndrome [4]. 
The diagnosis of Goodpasture syndrome is mainly based on the detection of glomeruli basal membrane positive antibodies and the more specific alfa-3 chain of type IV collagen positive antibodies. Direct immunofluorescence of the material obtained from a kidney biopsy exposes linear deposits of Immunoglobulin G (IgG). Therefore, a kidney biopsy provides a definite diagnosis of the syndrome. In optical microscopy, early changes characteristic for Goodpasture syndrome are seen as focal proliferative glomerulonephritits [4].

In patients with pulmonary involvement, chest-RTG images often include diffusive, bilateral and symmetrical perihilar consolidation. These abnormalities are often presented without the involvement of the apices, which makes it an uncommon clinical presentation. In the chest-CT: bilateral, diffusive changes to the alveoli are stated $[5,6]$.

The differential diagnosis of Goodpasture syndrome includes systemic diseases with inflammation of minor blood vessels, like granulomatosis with polyangiitis (GPA), systemic lupus, eosinophilic granulomatosis with polyangiitis (EGPA), microscopic polyangiitis, cryoglobulinemia [7].

Goodpasture-like syndrome includes renal failure and alveolar hemorrhage, often with a rapid progression. In this disease the anti-glomerular basement membrane antibodies are seldom present. Goodpasture-like syndrome can be pharmacologically-induced. For example, such an adverse reaction is seen in D-penicillamin-based therapy used in the treatment of some autoimmunological diseases like: scleroderma, primary biliary cirrhosis and Wilson's disease $[8,9]$.

\section{PRESENTATION OF CASES}

\section{Case 1}

A 39-year-old male patient was admitted to the Department of Thoracic Surgery due to a recurrent fluid in the right pleural cavity. Pleural fluid examination was carried out (cloudy, density 1.018, pH 7.0, WBC 18\%, mesothelium cells 3\%, undifferentiated large cells with hiperchromatic nucleus 45\%). The cytological analysis from the performed punctures suggested a neoplastic process. The patient was qualified for surgery during which decortication and a pleurectomy were performed. The subsequent histopathological examination failed to confirm the neoplastic etiology, instead providing a histological diagnosis of chronic fibrous pleuritis with purulence, atelactasis and subpleural fibrosis. The postoperative course was uneventful. Three weeks after the patient was discharged, he was re-admitted due to a respiratory tract hemorrhage. Coagulopathy assessment was done (Activated Partial Thromboplastin Time - APTT: 34.7 s, International Normalised Ratio - INR: 1.1, platelet - PLT: $576 \mathrm{~K} / \mathrm{ul}$ ). The chest computed tomography (CT) images (Fig. 1) and bronchofiberoscopy revealed the presence of a diffused heavily damaged right lower lobe with features of hemorrhage in the low-lobe bronchi. The patient was again qualified for surgical treatment. A right lower lobectomy was performed. The histopathological examination that followed stated the diagnosis of a massive chronic alveolar hemorrhage in the form of fresh hemosiderosis. Hemorrhagic changes involved the whole lobe. Furthermore, excessive lymphocytic interstitialitis with discrete fibrosis were also noted in a few locations. No necrotic changes to the vessels were observed. Upon such histological features, a diagnosis of Goodpasture syndrome or spontaneous pulmonary hemosiderosis was suspected. An inter-academic consultation was arranged with a re-examination of the histological material by Professor Aleksander Wasiutyński from the Department of Pathological Anatomy of the Warsaw Medical Academy, which confirmed the diagnosis of Goodpasture syndrome. During both hospitalizations the patient was treated with antibiotics (Sulfametoksazol and Trimetoprim, Ciprofloxacinum, Amoxicillinum, Clindamycin, Metronidazol). The patient was then later hospitalized at the Department of Pulmonary Diseases, where despite the atypical clinical presentation (unilateral changes, lack of renal involvement and negative immunological results) the diagnosis was upheld. A treatment based on Prednisone (doses from $60 \mathrm{mg}$ with reduction) from July 2006 to September 2008 was applied with good results. Last follow-up in 2009.

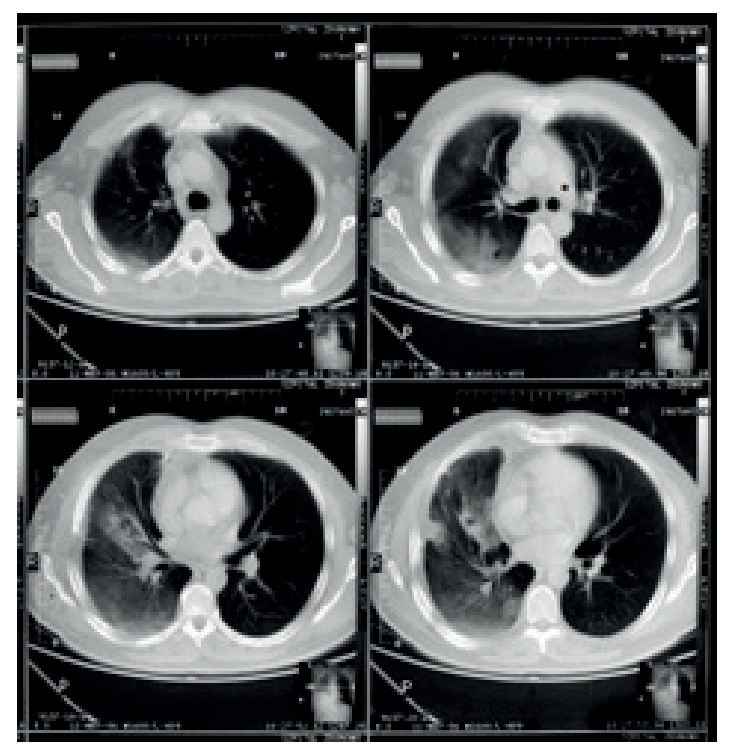

FIGURE 1. Computed tomography image of the thorax: presence of extensive "ground glass" type shadows in the middle and inferior areas of the right lung. Within the right middle lobe confluent diffusive areas are present

\section{Case 2}

A 53-year-old female patient was admitted to the Department of Thoracic Surgery due to a respiratory tract hemorrhage. The patient had no previous history of chronic diseases. She had been primarily diagnosed at the Department of Pulmonology 6 months earlier for the same symptoms, where she underwent a bronchofiberoscopy. During examination, an increase of bleeding in the right bronchi was found. After the applied treatment (Clindamycin) a full recession of hemorrhagic symptoms was observed. The patient was later transferred to the Department of Thoracic Surgery and qualified for surgery as an urgent case. In the CT of the thorax a typical image of ground glass opacities in the right middle lobe was 
found, corresponding to the presence of an alveolar hemorrhage. There were no thromboembolic lesions found in the pulmonary artery. During a subsequent bronchofiberoscopy the location of the hemorrhage was stated in the outlet of the middle-lobe bronchus (Fig. 2). A right middle lobectomy was performed. The postoperative period passed uneventfully. In the histopatological examination an inconclusive diagnosis of Goodpasture syndrome or Goodpasture-like syndrome was stated (Fig. 3).
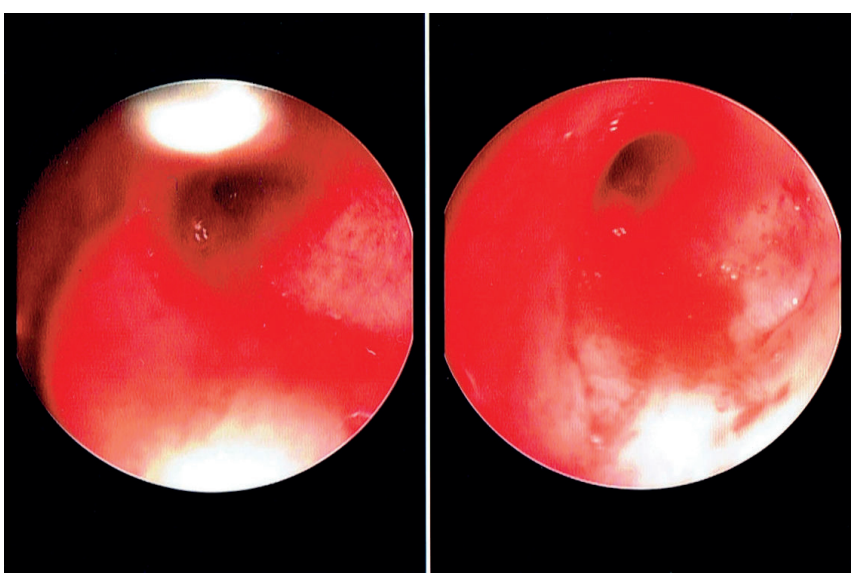

FIGURE 2. An image from the bronchofiberoscopy: bloody content in the outlet of the middle-lobe bronchus

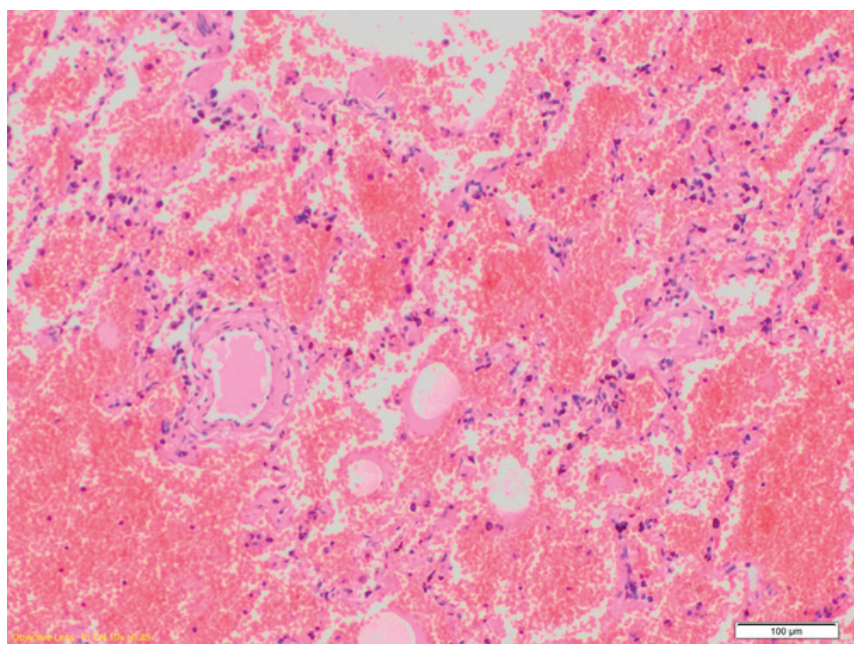

FIGURE 3. An image of the pulmonary tissue with the presence of confluent, fresh, intra-alveolar hemorrhage foci and numerous hemosiderophages. Additionally, features of slight interstitial fibrosis and minor foci of neutrophils and single eozynophils in the tissue stroma were found, some of them resembled a vasculitis of the minor vessels

\section{DISCUSSION}

This study describes 2 cases of recurrent, isolated, massive hemorrhage to the respiratory tract requiring surgical treatment. On the basis of a histopathological examination of the material obtained during surgery, the 1st patient was diagnosed with Goodpasture syndrome and the 2nd with Goodpasture syndrome or Goodpasture-like syndrome.
Goodpasture syndrome is a pulmonary-renal syndrome. Alveolar hemorrhage concerns around $40 \%$ of patients with the syndrome $[4,10]$. Isolated lung involvement occurs rarely - in around $10 \%$ of the patients $[2,3,5]$. The 1 st case described in this paper was found to have solely pulmonary symptoms in the form of a recurrent lower respiratory tract hemorrhage. The time interval between the occurrence of pulmonary symptoms and the development of glomerulonephrititis, described in literature, vary in length, but usually fit within the 8-12 month range - although much longer intervals have been reported [11]. Other authors' descriptions of respiratory tract hemorrhages in Goodpasture syndrome vary in intensity from minor hemoptysis to massive, recurrent hemorrhage. This symptom is characteristic for this disease. Nevertheless, it is very unspecific and often found in other disorders, especially those arising from an autoimmunological background [5]. The 1st patient suffered from a unilateral respiratory tract hemorrhage, although the pulmonary changes in Goodpasture syndrome are usually bilateral [7]. This was one of the difficulties that arose when attempting to identify the origin of the hemorrhage in the presented case.

In Goodpasture syndrome the histopathological examination of the material obtained during bronchofiberoscopy usually reveals the presence of blood and hemosiderine deposits in the alveoli as well as macrophages "stuffed" with hemosiderine (this presentation indicates the recurrent character of the hemorrhage, but it is very unspecific). Furthermore, vasculitis is also present [7].

In the described case there were no signs of vascular inflammation or necrosis in the specimen of the whole lobe. Only the presence of hemosiderine deposits and fresh alveolar hemorrhage features were confirmed. Such histological presentation could also indicate other diseases like spontaneous pulmonary hemosiderosis - which was considered in the differential diagnosis. This disease, just like Goodpasture syndrome, is manifested by a single or recurrent alveolar hemorrhage. Spontaneous pulmonary hemosiderosis affects mainly children in puberty with the adults (typically men under 30 years old) making up less than $20 \%$ of the patients. The histopathological presentation of the spontaneous pulmonary hemosiderosis is unspecific. It may include features of fresh alveoli hemorrhage, hemosiderine deposits and very rarely - vasculitis of the minor vessels. It lacks the presence of antibodies targeting cellular components. The diagnosis of spontaneous pulmonary hemosiderosis is often stated after excluding other possible reasons for alveoli hemorrhage [12].

Furthermore, especially if the immunological results were negative, apart from the auto-aggressive diseases, the differential diagnosis should also include pulmonary embolism and legionellosis [13]. In the presented patient there were no evidence of these diseases. Additionally, the negative immunological results hindered the diagnosis. In Goodpasture syndrome such symptomatology was described by Wierzbicki et al. [14]. The case of the patient described in our study was similar to the one reported by Wierzbicki et al., with a definitive diagnosis for both cases being stated only after the histopathological 
examination was undertaken [14]. Other authors also reported that the final diagnosis in patients free of renal damage features (at the moment of diagnosis) and presenting no anti-glomerular basement membrane antibodies could only be made after histopathological examination [15].

The 2nd case presented an isolated, unilateral, recurrent, massive respiratory tract hemorrhage in a middle aged patient. The patient was not exposed to any Goodpasture-like syndrome inducing factors. She was not treated with D-penicillamine or any other medicine similar in activity and her living environment was free of toxic factors that could possibly be a factor in the syndrome's development $[8,9]$. In addition, the patient did not display any signs of renal damage, which is a part of its typical symptomatology [8]. In Goodpasture-like syndrome, antibodies targeting the cytoplasm of the neutrophils are sometimes present (ANCA), rarely anti-glomerular basement membrane antibodies [8, 9]. In a series of 14 cases concerning Goodpasture-like syndrome, presented by Derk and Jimenez, only 1 patient was anti-glomerular basement membrane positive and the pulmonary changes of their patients were always bilateral [8]. In the 2nd patient described in this paper the final diagnosis of Goodpasture syndrome or Goodpasture-like syndrome was based upon the histopathological examination of the extracted lobe obtained during thoracotomy.

The cases presented in this paper show the diagnostic difficulties in determining the cause of a massive respiratory tract hemorrhage for which the only treatment is surgical intervention - lobectomy. Each patient had an atypical clinical presentation. Furthermore, the postoperative histopathological examination of the affected pulmonary tissues turned out to be the most important tool in determining the diagnosis.

\section{CONCLUSIONS}

1. Both Goodpasture syndrome and the so-called Goodpasture-like syndrome may manifest themselves as isolated massive respiratory tract hemorrhages without any renal abnormalities or changes in the immunological test results.
2. In the case of an atypical clinical course and negative immunological results, both syndromes may be diagnosed by means of a histopathological examination.

\section{REFERENCES}

1. Hellmark T, Segelmark M. Diagnosis and classification of Goodpasture's disease (anti-GBM). J Autoimmun 2014;48-49:108-12.

2. Dammacco F, Battaglia S, Gesualdo L, Racanelli V. Goodpasture's disease: a report of ten cases and a review of the literature. Autoimmun Rev 2013;12(1):1101-08.

3. Huart A, Josse AG, Chauveau D, Korach JM, Heshmati F, Bauvin E, et al. Outcomes of patients with Goodpasture syndrome: A nationwide cohort-based study from the French Society of Hemapheresis. J Autoimmun 2016;73:24-9.

4. Alenzi FQ, Salem ML, Alenazi FA, Wyse RK. Cellular and molecular aspects of Goodpasture syndrome. Iran J Kidney Dis 2012;6(1):1-8.

5. Marciniak-Sroka J, Niżankowska E. Zespół Goodpasture’a. Pol Arch Med Wew 2000;104(6):889-95.

6. Mayberry JP, Primack SL, Müller NL. Thoracic manifestations of systemic autoimmune diseases: radiographic and high-resolution CT findings. Radiographics 2000;20(6):1623-35

7. Greco A, Rizzo MI, De Virgilio A, Gallo A, Fusconi M, Pagliuca G, et al. Goodpasture's syndrome: a clinical update. Autoimmun Rev 2015;14(3):246-53.

8. Derk CT, Jimenez SA. Goodpasture-like syndrome induced by D-penicillamine in a patient with systemic sclerosis: report and review of the literature. J Rheumatol 2003;30(7):1616-20.

9. Gaskin G, Thompson EM, Pusey CD. Goodpasture-like syndrome associated with anti-myeloperoxidase antibodies following penicillamine treatment. Nephrol Dial Transplant 1995;10(10):1925-8.

10. Fox HL, Swann D. Goodpasture syndrome: pathophysiology, diagnosis, and management. Nephrol Nurs J 2001;28(3):305-12.

11. Jóźwiak L, Orłowska-Kowalik G, Książek A. Zespół Goodpasture’a współistniejący z nieswoistym zapaleniem jelit u 28-letniej kobiety. Pol Arch Med Wew 2004;62:1467-71.

12. Korzeniewska-Koseła M. Uogólnione krwawienie pęcherzykowe. Nowa Med 1999;100:13-7.

13. Sabani E, Sarafidis PA, Lazaridis A, Kouloukourgiotou T, Stylianou K, Pantzaki A, et al. A Case of Pulmonary-Renal Syndrome Leading to the Diagnosis of Legionnaires' Disease. Case Rep Nephrol 2016;2016: article ID 4250819. doi: 10.1155/2016/4250819.

14. Wierzbicki P, Smoszna J, Wańkowicz Z. Zespół Goodpasture’a - stale aktualny problem kliniczny. Pol Merkuriusz Lek 2000;9(54):855-7.

15. Gawryluk D, Bączkowska T, Pazik J, Wiatr E, Pawłowski J. Nawracające krwawienia do pęcherzyków płucnych w przebiegu zespołu Goodpasture'a. Pneumon Alergol Pol 2005;73:79-84. 